\title{
NON-PARTISANSHIP IN MUNICIPAL AFFAIRS AS ILLUSTRATED BY NEW YORK EXPERIENCE
}

\author{
BY JOHN J. MURPHY
}

New York City

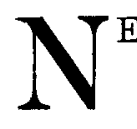

EARLY a quarter of a century since, a group of high-minded citizens of New York evolved a theory of municipal government based upon a perfectly logical principle. Had they been less high-minded they might have been suspicious of the very fact that it was perfectly logical. No perfectly logical principle functions efficiently when applied to human affairs. Were it otherwise John Jay Chapman would be the greatest politician in the United States for no one has more relentlessly applied logic to the solution of governmental problems. Instead of holding such a position, he is merely the high exemplar of a small group of men who admire above everything else, nobility of character and consistency of purpose.

The theory was that, although men might differ on political questions, all decent citizens were a unit in favor of good government and honest administration. Under the leadership of the late Seth Low, of venerable memory, this idea won its greatest public favor in 1897. Although he was defeated for the mayoralty, he polled 150,000 votes for the idea. True, he was elected in 1901, but the fundamental idea of 1897 was sacrificed to achieve the victory, for of the allies who came together to overthrow Tammany in that year, not 20 per cent even pretended to any faith in the non-partisan idea. Eighty per cent of the participants were simply a coalition of revolting Democrats and of Republicans who saw no other way of inflicting a defeat on their party rival. Their ideals of government were little, if anything, higher than Tammany's; they were the strictest kind of party men.

At what point did the logical principle break down in application? Simply in its failure to properly take into account the basis of parties and partisanship. The assumption that parties exist to advance the ideas with which they are identified in the public mind, is almost wholly erroneous. Parties take up ideas to keep themselves alive. The Republican party is sometimes supposed to exist for the perpetuation of the principle (save the mark) of protection. As a matter of fact the Republican party takes up protection as one means of keeping itself going. So the Democratic party at one time seemed to exist to advocate the remonetization of silver. But the relegation of that idea to oblivion did not cause the party to disintegrate. 
Parties take up issues as a merchant replenishes his stock; when the public demands something new, the merchant brings out the new fashions. The primary purpose of the party and the merchant is the same, to make a living. Parties have an existence entirely independent of the principles they advocate or profess.

The basis of their life is the association of like-minded men, men who can combine for effective action, men whose attraction for one another is on the whole greater than their repugnance to each other. If this thought be kept in mind, the brief existence of new parties will be understood. New parties spring up to advocate ideas, which for the time being are strong enough to tear men away from old associations. These ideas are either rejected, enacted into law or stolen by one or other of the regular organizations. Then the components of the new party seek their old alignments.

When, therefore, non-partisanship in municipal affairs was tried, under leaders as unselfish as any who have ever led such a movement, men found themselves thrown into association with other men with whom they were not congenial. The Republican mind and the Democratic mind, when thrown into juxtaposition, even for so unimpeachable a cause as good government, generate antagonisms. Hence the constant tendency was to fly apart. What we have seen in most non-partisan movements (so-called) is really a coalition of minority groups to defeat an opponent stronger than any one of them, but unable to defeat them all combined. Were any of these groups in the majority it would not consider nonpartisanship as a principle of action for a moment. Fusion movements are often useful and practicable, but they should not be confounded with non-partisan movements. They are omni-partisan rather than nonpartisan. All men who have any positive qualities are partisans.

After many years of belief in and struggle for, the realization of the non-partisan idea, I am forced to admit that it runs counter to a natural law which is stronger than logic. The old struggle of the realist and the idealist, the head and the heart, efficiency and humanity, the imperialist and the democrat, inevitably wrecks any attempt to combine these antagonistic elements into a permanent movement. 